\title{
SPECIAL SECTION: COMMUNITY APPROACHES TO PROBLEMS: BEYOND INDIVIDUAL AND FAMILY SOLUTIONS
}

\author{
HELEN GREMILLION \\ Unitec Institute of Technology, Auckland, New Zealand
}

I am delighted to introduce this special issue, which brings together a range of community approaches to problems which counselors and social workers might otherwise address through more conventional individual, family therapy, or social work interventions. Each of these articles proposes a direct inclusion of social or cultural engagements as part and parcel of work alongside clients. This kind of therapeutic and social work has implications for theory-for example, how to locate problems and alternatives to them-and implications for practice: how is community defined "on the ground?" In what arenas do "therapy" and social work take place?

These articles share some theoretical legacies. Primarily, each paper critically questions long-standing assumptions within counseling and social work that locate problems and solutions within individuals. As Walters, Carter, Papp, and Silverstein (1988) first argued some time ago with reference to gender, even systems approaches which appear to transcend individuality can reinforce culturally dominant ideas about individual roles, responsibilities, or transactions. In contrast, the authors contributing to this special issue posit what Johnella Bird (2004) has called a relational "I": an understanding of identity as intimately and ongoingly created within a matrix of collective and mutable meanings and practices. With this understanding, change occurs via transformational action in wider social contexts. As McNamee and Gergen (1999) suggest, problems and their alternatives exist in a social realm of relational responsibility.

The authors here demonstrate a way of thinking and working that shares much with Winslade and Williams's (2012) book Safe and Peaceful Schools, which addresses the problem of bullying. Rather than focus on individual change, Winslade and Williams aim to change bullying relations. Such a project of change engages peers and bystanders to help create and grow a preferred social reality in schools, guarding against the isolation and self-policing that can result from more conventional approaches to bullying. The contributors to this special issue document similar approaches to the particular problems they address. As Peggy Sax notes 
in her contribution, citing Shalif (1999), a community orientation in counseling work involves "getting therapy out of the room and getting out of the room into therapy" (p. 181). In other words, with a community approach, the sites for the work shift from more traditional expectations, along with the location of problems and their alternatives. Where the work takes place, and alongside whom, can vary. The positioning of the counselor or social worker can vary as well.

In "Reclaiming Community out of Personal Catastrophe" (pp. 30-42), Sax documents her counseling and community work with two clients who have suffered the loss of loved ones through dramatic and very difficult circumstances. Rather than focus on any particular analysis of grief and loss, Sax shows how painful experiences can be transformed through a range of social service engagements and ally relationships. Positioning herself as an ally, Sax supports her clients to link with other clients and community members who have had similar experiences, and to become actively involved in community work and in local organizations such as hospice services and the humane society, as a way of "giving back" and contributing meaningfully to others' lives. Here, the constitution of community and the locations of the therapeutic work are shaped by what Sax terms clients" "own naturally sustaining webs of connection" (p. 30). Opportunities for healing and communal collaboration are discovered and grown when clients' desires and hopes resonate with them. Key to this set of ideas is the metaphor of "rhizome" (Hoffman, 2009), which unlike the engineering-based metaphor of "systems" is rooted in an understanding of processes in the natural world as embodied, unpredictable, and web-like.

The metaphors and practices that underpin counselors Kay Ingamells and David Epston's contribution, "A Family and Community Approach to Stealing” (pp. 43-55), are in some ways quite different from Sax's. Ingamells and Epston share with Sax a set of ideas and interventions that are based in narrative therapy and community work: for instance, a decentering of counselor knowledge about problems-though counselor knowledge remains influential (White, 2000) — and an appreciation of the power of "definitional ceremonies" (White, 2007) for articulating and growing new and preferred identities. But Ingamells's and Epston's approach is more centrally situated within a narrative metaphor of story. What stories of a young person's stealing are helpful to tell, considering their lived and relational implications, both with clients and among professionals? Drawing on Epston and Seymour (2008), Ingamells and Epston themselves tell a story of Ingamells's counseling practice with a family that includes 12-year-old Dilip, who has a reputation of stealing. Stories of stealing, and an examination of its effects, are quickly taken over by stories and practices of honesty. The bulk of Ingamells's work with this family is a re-storying of identity through honest actions. The conditions of possibility for these are carefully arranged, and they are reported and celebrated among Dilip's family members and friends. This approach is fairly directive about solutions, and yet there is a strong collaboration with a well-defined community surrounding Dilip and his family.

Cottle, Hughes, and Gremillion's article, "A Community Approach to Palliative Care" (pp. 56-69), returns us to the topic of bereavement, this time with a focus 
on living with death and dying in Aotearoa New Zealand. This paper documents hospice-based palliative care that engages Māori clients in helpful and meaningful bereavement experiences (Māori are the indigenous people of New Zealand). The hospice work described here is interdisciplinary and ecosystemic, and is also rooted in cultural concepts and practices in ways that extend systems thinking. The authors show how social work contributions to palliative care, which challenge individualized and medicalized responses to death and dying, are transformed when socially marginalized cultural discourses are considered central. The article draws on a rich case study and on Payne's (2005) critique of ecosystems approaches to social work. The positioning of the author/practitioners here is bi-cultural: a partnership is created between practitioners and clients, and an ecosystems and "provider" approach clears space for, and sits alongside, Māori-determined community development and support, which in turn shapes professional practice. This work is multi-sited.

These articles engage constructs of community that are not only alternative to, but also challenging of conventional counseling and social work practices. I hope you will find the range of interventions, metaphors, and practitioner positionings presented here to be instructive and enlightening.

\section{REFERENCES}

Bird, J. (2004). Talk that sings. Auckland, New Zealand: Edge Press.

Epston, D., \& Seymour, F. (2008). Community approaches—real and virtual—to stealing. In D. Epston (Ed.), Down under \& up over: Travels with narrative therapy (pp. 139-156). London: Karnac Books.

Hoffman, L. (2009). Notes on a starfish federation. Retrieved November 9, 2009, from http:// www.rhizomenetwork.com/lynn-hoffman-notes-for-a-starfish-federation/

McNamee, S., \& Gergen, K. (1999). Relational responsibility: Resources for sustainable dialogue. London: Sage.

Payne, M. (2005). Modern social work theory (3rd ed.). New York: Palgrave Macmillan.

Shalif, Y. (1999). Reflections on a Jewish journey. In T. C. Collective (Ed.), Narrative therapy and community work: A conference collection (pp. 178-189). Adelaide, Australia: Dulwich Centre Publications.

Walters, M., Carter, B., Papp, P., \& Silverstein, O. (1988). The invisible web: Gender patterns in family relationships. New York: Guilford.

White, M. (2000). Reflections on narrative practice: Essays and interviews. Adelaide, Australia: Dulwich Centre Publications.

White, M. (2007). Maps of narrative practice. New York: W. W. Norton.

Winslade, J., \& Williams, M. (2012). Safe and peaceful schools: Addressing conflict and eliminating violence. Thousand Oaks, CA: Corwin Press. 
Copyright of Journal of Systemic Therapies is the property of Guilford Publications Inc. and its content may not be copied or emailed to multiple sites or posted to a listserv without the copyright holder's express written permission. However, users may print, download, or email articles for individual use. 